\title{
Money and Monetary Policy for the Twenty-First Century
}

\author{
Jerry L. Jordan
}

\begin{abstract}
This essay challenges the conventional wisdom about money and monetary policy. The role of money in fostering prosperity is a function of the quality, as well as the quantity, of money. Inflation always harms the performance of an economy. Deflations caused by productivity and innovation can be virtuous. A definition of a non-inflationary environment is set forth. Rapid real growth and low unemployment cannot cause inflation. There is no trade-off between inflation and employment. Higher commodity prices or "weak" exchange rates cannot cause inflation. High market interest rates are a symptom of inflationary policies. Low interest rates are a reflection of successful antiinflationary policies, not "easy money." (JEL E41, E42, E51, E52)
\end{abstract}

Federal Reserve Bank of St. Louis Review, November/December 2006, 88(6), pp. 485-510.

\section{THE BASICS OF MONEY}

Modern market economies would not be possible without financial stability. However, as events around the world in the past decade demonstrated, financial institutions are not sound and payments systems are not efficient when the value of money is not stable. Decades of experience have demonstrated that prosperity is undermined when the value of money fluctuates. Stabilizing the value of money has become the primary, if not the sole, objective of central banks around the world. This is an essay about money-both the meaning of the word and the various ways people have sought over time to stabilize its value. The importance of stable money-and the roles of governments and central banks in providing it-will be presented in a different light than it is in the conventional dialogue.

In a superficial sense, after decades of increase, the number of "monies" circulating in the world began to decline during the final decade of the past millennium. It is superficial because many of the national currencies did not qualify as "money" in the full sense. There are only a few "standards of value" that do not need to be linked to-or defined in terms of-some other monetary unit. In the same sense that ten "dimes" or four "quarters" are the same as one U.S. dollar, many small-country currencies are defined in terms of the major currency they are tied to.

For the few currencies that do serve as standards of value, the issuing central banks must take actions, which collectively are referred to as "monetary policy." Such policy actions determine the "quality" of the money over time. A money's quality is inversely related to the quantity of other real resources that are used in the economy alongside money to conduct money-type functions. In places in the world plagued with unstable money, people spend much of their time getting paid more frequently, dealing only in cash, making more frequent purchases, or hiring expensive

Jerry L. Jordan was the president of the Federal Reserve Bank of Cleveland from March 1992 to January 2003. Previously, he was director of research at the Federal Reserve Bank of St. Louis. He is a senior fellow at the Fraser Institute and an adjunct scholar at the Cato Institute. This article was presented in part as the Homer Jones Lecture, March 8, 2006, in St. Louis Missouri, after being printed in Critical Issues Bulletin 2005, by the Fraser Institute; sections of the article are reprinted here with permission. The author thanks John Chant, Steve Easton, and Anna Schwartz for comments on drafts of this article.

(C) 2006, The Federal Reserve Bank of St. Louis. Articles may be reprinted, reproduced, published, distributed, displayed, and transmitted in their entirety if copyright notice, author name(s), and full citation are included. Abstracts, synopses, and other derivative works may be made only with prior written permission of the Federal Reserve Bank of St. Louis. 
money managers and financial advisers. That is, having money of lower quality means that more time, effort, and resources are employed in gathering information about relative prices and conducting transactions. Those resources could have been used to raise the "potential output" of the economy, which is the social payoff for policies that maintain sound money. The frequently referred to, but little understood, "cost of inflation" is the loss of output over time resulting from deterioration of the quality of money.

\section{The Nature of Money}

My very great teachers (Alchian, 1977; Brunner and Meltzer, 1971) taught that a society uses as money that entity that economizes best on the use of other real resources to gather information about relative prices and to conduct transactions. This makes clear that the common-but wrongstatement of Gresham's Law about "bad money" driving out "good money" needs to be restated. What we have observed through the millennia is that high-confidence monies drive out lowconfidence monies (Hayek, 1976, p. 29; Mundell, 1998).

Sometimes economists treat money as a factor of production that is separate from, and in addition to, land, labor, or capital. This is not a useful way to think about the role of money in society. It is derived from-and maybe reinforces-the idea that there must be enough money in circulation to "meet the needs of trade." A more fruitful way to think about the role of money in a market economy is one in which sound money liberates resources, especially resources used to gather information and to conduct private transactions. This view draws attention to the importance of the quality of money. That money facilitates transactions appears to be clear to everyone; its role in enhancing market knowledge about relative prices, however, is less well understood.

Money's effectiveness depends largely on its quality. The quality of money is high when the value of money is stable. Money prices provide households and businesses with reliable information about the relative costs of goods and services. They can make sound economic decisions and this, in turn, fosters economic prosperity.
The economic efficiency that comes from a stable monetary unit of account is one of the pieces of a Hayekian infrastructure that a market economy requires. That is, a market economy requires a foundation of enforceable property rights, generally accepted accounting principles, sound financial institutions, and a stable currency. Where public contracts are not honored and private contracts are not enforced, markets are impaired. Where title to property is not certain, normal banking is not possible. Where financial statements are not reliable, investment opportunities are obscured. Where the purchasing power of money is not stable, resources are wasted in gathering information or are tied up (hoarded) as stores of value are used in producing and consuming the wrong things.

\section{Money, Prices, and Income}

The prices of things people buy and sell and in which they invest are expressed in terms of money units. Changes in the money prices of goods and assets convey information. If an economy's monetary unit is known to be a stable standard of value, then changes in money prices will accurately reflect changes in the relative values of goods and assets. That is, price fluctuations signal changes in the demand for, and supply of, goods and assets; resources are then shifted toward more valued uses and away from those less valued. This is essential in order for the economy to achieve the most economically efficient aggregate output. In other words, standards of living will be highest when all price changes can be interpreted as relative price changes. Similarly, all changes in interest rates would be changes in real interest rates-a reflection of changes in people's preferences about time, changes in the pace of innovation, or changes in the economy's endowment of productive resources.

Unfortunately, in the world of fiat money, ${ }^{1}$ one can never be absolutely certain that observed changes in the prices of specific things or changes in interest rates reflect real events such as crop

\footnotetext{
1 Irredeemable paper currency that does not rest on a specie basis such as gold but derives its purchasing power from the declaratory fiat of the government issuing it.
} 
failures, so mistakes are made in the allocation of productive resources. As a consequence, the well-being of the society is less than optimal. A form of monetary static (like a distracting noise) in the pricing of goods and services occurs when the standard of value-money-does not mean the same thing over time. This static means the signals that are coming to decisionmakers from observed price changes cannot be relied upon with certainty when the use of productive resources is shifting.

In economies where changes in money prices are contaminated by the changing purchasing power of money, false signals are being sent to businesses and households. Bad decisions are being made, and resources are being misallocated. Standards of living-real incomes-fail to rise at their potential rate. Nominal interest rates (that is, the kind you see quoted every day) respond to shifting expectations about the future purchasing power of money. Changes in real interest rates are obscured, so resources are misallocated. Since saving and investment decisions are affected, growth is impaired.

The objective of monetary policy is to minimize the misinformation associated with the constantly changing (relative) prices of things. Absence of inflation is the ideal condition in which businesses and households make all decisions based on the assumption that all price changes currently observable or expected in the future are relative price changes; that is, they reflect changes in the underlying demand for, or supply of, everything. Naturally, if all price changes are relative price changes, for every observed or expected rise or decline in some prices there must be corresponding price declines and rises in other prices. ${ }^{2}$ For this condition to prevail, peoplewhile they know that some prices will rise and others will fall-must anticipate that on balance they are safe in assuming the monetary standardmoney-will buy the same universal array of goods over time. When innovation occurs and new goods are invented, the average well-being of the society is improved but not because the information content of money has changed.

2 Appropriately weighted.
Innovation involves "creative destruction"-the economic value of something old is reduced by the discovery of a new product or more efficient way of producing the old product. Relative prices change; a market system treats such changes as signals that resources are better used by shifting away from the old and toward the new.

A real increase in particular prices or wages occurs when there is a shift in demand away from some other good or factor input ${ }^{3}$ and toward that good or factor. When "improved efficiency" means discovering ways of using the same amount of labor but less of other factor inputs to produce the same output, a real wage gain occurs. In such a circumstance, observed wage increases would be associated with decreases in output prices to the extent that the quantity of the good produced increases as a result of the improved productivity.

An innovation that generally improves productivity in an economy will be associated with higher real returns to productive capital (including human resources such as labor). The resulting increase in observed interest rates-which are themselves relative prices and subject to changeis a part of the mechanism by which resources are bid to their higher-valued uses. As will be discussed later, if governmental (monetary) policies sought to prevent the market from bidding up interest rates, the resulting expansion of the central bank's balance sheet would cause monetary units to be created at a more rapid rate than people desire to add to their stocks of money balances. The effects would be observed in an acceleration of aggregate spending growth as people seek to exchange the excess balances for things they prefer. The bidding of the excess money units for other things causes the money prices to risemore money units to acquire the same thing. Price signals are then distorted by the falling purchasing power of the money used in the economy.

The challenges to monetary policymakers in formulating and implementing policy actions to minimize inflation or deflation will be discussed in some detail below. Here, the important point is that frequent changes in the prices of things

3 Economists refer to the materials used to make things-wood, metal, plastics, etc.—as "factor inputs." 
and changes in market interest rates are normal occurrences in a market economy, and an understanding of how and why they are changing is important to both policymakers and the rest of us.

\section{Inflation}

It would be hard to get agreement on a definition of inflation and even more difficult to get agreement on an acceptable measure of inflation. We have chosen instead to define the conditions that would prevail when there is an absence of inflation or deflation. Common usage of the term "inflation" is misleading because it confuses cause and effect. Often people think that inflation occurs because "prices are rising." But, that is too simple. Such a diagnosis often leads naive politicians to think the appropriate prescription is either to put controls in place to prevent prices of things from going up; or they think the task is to ensure that incomes rise at least as rapidly so that standards of living do not erode. Both prescriptions are wrong.

"To inflate" certainly means "to make larger," but what is increasing is the number of money units required to purchase the same basket of goods over time. The diagnosis should be that money units are being created at a faster rate than people want to add to their holdings of them. "Too much money chasing too few goods" is the familiar cause of inflation. The appropriate prescription is to avoid creating money at a pace that is faster than people want to add to their money balances. How policymakers seek to do this is discussed in the boxed insert.

The obvious political risk of talking as though inflation means that prices of things and people's wages are rising is that people come to fear that policymakers are out to deny them the welldeserved wage increase or higher price for their products that other people seem willing to pay. Public surveys reveal that people form ideas about inflation based on prices of things they buy. They rarely see higher prices of things they sell as anything other than just rewards for their labors.

The expressions "price stability" or "stable prices" are not more helpful. Prices of thingsboth goods for current consumption and investment assets-are constantly changing. All innovation implies lower (relative) prices for previous goods and technology. The familiar pattern for all newly introduced goods is for their prices to fall as methods of production and distribution are improved and as economies of scale are achieved. Conversely, as wealth rises, people spend a declining share of their income on certain "necessities" and larger shares of their income on goods thought of as luxuries. Such shifts in consumption patterns may be associated with rising prices of the more sought-after goods. These are natural manifestations of a market economy. It would be highly undesirable to have-and to have policies designed to maintain-stable prices.

People know very well that the money prices of some things will rise (cars, concert tickets, impressionist paintings, greens fees, tuition, etc.) even though they cannot be sure by how much. Money prices of other things will fall (refrigerators, telephone calls, computers, televisions, VCRs, carpets, microwave ovens, etc.), even though they cannot be sure by how much. Most of the time for most things (food, gasoline, clothing, prescription drugs, etc.) they cannot be too certain whether the money prices in the future will be higher or lower. Such uncertainties cannot be eliminated from a market economy. As a consequence, people have always chosen to use as money (subject to the effectiveness of criminal prohibitions by governments) the entity that their own experience suggests is more likely to be exchangeable in the future for known quantities of things they desire. Uncertainty about present and future relative values of things is precisely why people hold money balances at all. When alternatives are available, they will choose to use as money the currency they are least uncertain about with respect to future money prices. Because people know they get hurt by inflation, for over 40 yearsfrom the 1930s to the 1970s-the U.S. government made it illegal for American citizens to hold gold as a way of protecting themselves.

Time and other resources are required to shop-to gather information about relative prices of various goods, services, and investment assets. People will naturally prefer to use the monetary units that economize best on the use of their time and productive resources to gather information 


\section{MONEY IS NOT INCOME}

As noted earlier, even the word "money" cannot be used without ambiguity. It would be hard to find anyone who would admit to having more money than they want. But, their behavior suggests otherwise. Every purchase or investment involves a reduction in money holdings. Acquiring money balances requires selling something or spending at a slower rate relative to cash income. The confusion comes from the unfortunate popular habit of using the word money to mean income or wealth. It is natural for humans to desire more income-ability to consume. Money is the means by which indirect exchange takes place. It is a good that is held for the services it renders. Like any other good, a person can certainly be holding more money balances than desired relative to other things. When one's money balances are judged to be too large, disposing of excess money in favor of some thing is the least costly adjustment one can make.

In truth though, people do not normally desire to hold something simply because society treats it as money. Rather, they desire to have available claims to consumption-they want to buy things. Naturally, how much they can buy will depend on the prices of things in money units, so the amount of money they hold will depend on how much they expect things to cost. They form their expectations about how much things will cost in the future based on the experiences they have had in the past. If they generally have observed that the money prices of virtually everything they buy are always rising - a condition usually referred to as inflation-they are rational in thinking that will also be the case in the future. Under such circumstances, their current money holdings will be, on average, smaller than if they thought that the money prices of at least some of the things they want to buy will be lower in the future.

about relative prices and to conduct transactions. In recent decades, the world has had ample opportunity to observe ordinary people in Latin America, the former Soviet Republics, and central Europe choose to use U.S. dollars (and, increasingly, euros) rather than the currency supplied by their own governments. Obviously, they do so based on an expectation that the information available to them regarding the relative values of things is more reliable when denominated in dollars than in rubles, pesos, dinars, or bahts!

Bad experiences have taught most people that neither inflation nor deflation enhances economic performance. What also occurs, but is not as easy to observe, is that unanticipated inflations and deflations induce redistributions of wealthespecially between debtors and creditors-but they leave the average standard of living lower. According to a former Governor of the Federal Reserve, "a place that tolerates inflation is a place where no one tells the truth." He meant, of course, that true changes in the relative values of things cannot be observed from stated prices when the purchasing power of money is not stable.

An appropriate policy with regard to money would be to create the institutional arrangements that minimize the uncertainty that people encounter about the money prices both of goods available for current consumption and of investment assets. Individuals not only want to exchange the proceeds of their current labors for immediate consumption, they want to minimize uncertainty about their future ability to exchange various savings and investment assets for subsequent consumption. The types of money that exhibit the best track records for minimizing these information costs will be the preferred monies.

\section{Money and Interest Rates}

A confusion arising from the popular usage of the word "money" is that bankers claim to lend money and bank customers claim to borrow 
money. But, people do not increase their indebtedness in order to hold greater idle cash balances! The extension of credit by financial intermediaries does not alter the amount of money in the economy. Nevertheless, the unfortunate expressions"borrowing money" and "lending money"contribute to an erroneous idea about the relationship between the "amount of money" and observed interest rates. People (and their elected representatives) believe that interest rates would be lower if only there were more money available. This Ptolemaic view of the world persists even in the face of much sad experience that countries "enjoying" rapid money growth have high interest rates.

People hold a variety of financial assets-in addition to money-as stores of value. Often these assets are claims to certain amounts of money units at various times in the future. But, they do not want a certain amount of money in the future. They want to buy things. If they think the prices of things they will want to buy in the future will be higher, they know they will have to have more money units. Being able to earn higher interest rates on their assets is one way of having the greater amount of money that will be required by the expected higher prices of things. By the same token, borrowers of money are willing to pay higher interest rates if they expect their investments to generate larger volumes of money units as the money prices of things rise.

There is a common fallacy that "low" interest rates can "cause inflation" and that "high" interest rates are part of the solution. This is completely backward. When people-both businesses and households—start to anticipate that prices will be rising faster in the future, they make adjustments. Sometimes they make purchases sooner than otherwise to "get ahead" of the price rise. They may even go into debt to do so. They also seek to minimize any "idle balances" they hold in the form of cash or low-yielding balances in their checking accounts. But, while one family or one business may reduce its money holdings, the economy cannot do so. Actions by anyone to spend or invest only increases someone else's money balances. If everyone is trying to do the same thing, prices of goods and assets will get bid up- the real purchasing power of money falls-and higher interest rates will have to be offered to induce people to hold-rather than spend-the stock of money in circulation.

These market dynamics explain why higher interest rates are always and everywhere observed in the places where the value of money is falling fastest, while the lowest interest rates are observed where money is holding its value. There is only one monetary policy that can produce low interest rates: a policy of stable money. Once people start to expect the value of money to erode- the average of money prices to rise-observed interest rates can also be expected to rise. Any attempts to resist these natural market dynamics artificially will only make matters worse.

Even when businesses and households in an economy expect the value of money to be stable over time, there will be fluctuations in interest rates that reflect the changing pace of innovation, agricultural developments, natural disasters, wars, and other real events. Monetary authorities cannot avoid the need to analyze the forces tending to alter interest rates. Those market dynamics emanating from a monetary imbalance must be responded to. Errors in interpreting the forces operating to change interest rates has been the most common source of mistakes in the formulation of monetary policies in the modern world.

\section{Money and Exchange Rates}

People in every modern economy buy things from, and sell things to, people in other countries. How much they have to pay when they buy and how much they can get when they sell depends on the exchange rate between the domestic money and the money of the other country. The exchange rate between any two currencies depends on many things, including the inflation rates of each country and "acts of God" in one of the countries.

Wealth gains and losses in one country can result from changes in the exchange rate caused by developments in the other. When international terms of trade are altered by foreign developments-wars, agricultural conditions, etc.-there are redistributional effects in the domestic economy: The effects on import-competing firms is opposite to that on exporting firms, and the prices 
of tradable goods change relative to the prices of non-tradable goods. Furthermore, asset prices are influenced differently than goods prices. In all, many prices are affected, in different directions, with some people being positively or negatively affected relative to other people. None of these developments, though, has any certain effect on the stability of the domestic currency.

Even though price indices that include foreign goods-and domestic goods that compete with foreign goods-may increase or decrease as a consequence of international developments, it is not correct to identify such statistical observations as inflation or deflation. A shortfall of the coffee crop will influence coffee prices in importing countries. And, to the extent consumers pay the higher prices, they will experience a real income loss and consequently will purchase less of other things. What is observed is the higher price of coffee in the price statistics. What is not so readily observable is the associated lower demand for, and prices of, other things compared with what otherwise would have occurred. Relative prices have changed, but the average of prices depends on the income and substitution effects and the choices people make.

It is common-but wrong-for someone to say that "higher inflation is caused by higher costs of imports such as oil." What is true is that misinterpretation of a "price shock" caused by a change in the external exchange rate or by a real event such as a sudden drop in oil production can result in a mistake in monetary policy. Such misinterpretations and policy mistakes have frequently resulted in inflations (and deflations) that could have been avoided.

\section{Money, Growth, and Employment}

Contrary to simple intuition, one often sees news reports suggesting that "too much" economic growth will reduce the purchasing power of money-will "cause inflation," in familiar language. Yet, every person knows that a bumper crop of anything will yield lower prices and a poor harvest will be followed by higher prices. It is simply not logical (or correct) to argue that an increase in production will foster a general rise of prices. Concerns that faster total growth of out- put in the economy will cause a fall in the purchasing power of money-inflation-are simply wrong. ${ }^{4}$ Similarly, it is false to say that "too many people working” or "too low unemployment" can "cause inflation."5

Market economies have an inherent tendency to grow. How much growth occurs depends on incentives for working, for achieving productive efficiencies, and for introducing new products. In addition to tax laws and regulation, economic policies influence these incentives by fostering a monetary regime that provides reliable information about the relative values of productive resources, both in the present and in the future. That happens only when the monetary unit employed by the economy is of known and stable value. Anything less than stable money gives inaccurate signals about relative values, so resources are not allocated to their most productive uses. Growth, consequently, is less than it would be if money prices could be relied upon to reflect relative underlying supplies of, and demands for, productive resources accurately.

\section{Money and Productivity}

Traditionally, economists talk about things being produced using some combinations of land, labor, and capital, where capital is taken to mean tools, machines, buildings, and so on. Productivity-productive efficiency-improves when the same output can be obtained with less of at least one of these inputs. As noted earlier, economists sometimes include "money" in the production function, as a factor of production that is in addition to land, labor, and capital. As such, the quantity of money appears to be an alternative to (or maybe in addition to) lumber, copper, workers, or other factors. This unfortunate way of thinking about the role of money in the economy tends to be derived from-and maybe to reinforce-notions that there is "not enough money" in circulation. Such a false diagnosis is dangerous because it usually is accompanied by a prescription that

4 For a discussion of why rapid growth does not cause inflation, see Federal Reserve Bank of Cleveland (2000).

5 For further discussion of these issues, see Federal Reserve Bank of Cleveland (1999). 
the monetary authorities can make people better off by creating money units at a faster rate. That is certainly wrong.

It is easy to imagine, and probably common, for the lending officer of a bank to respond to a customer's request to borrow more funds by saying, "I would like very much to lend you some (more) money but the central bank is making credit very tight and I have no more to lend...how about golf on Sunday?" The would-be borrower is left with the impression that the currently available stock of money is already being "used" by somebody else and that the central bank is preventing him from expanding his business by failing to increase the total availability of money. A popular (but wrong) conclusion is that the output of the economy is being restrained by the inadequacy of money growth.

The alternative way to think about the role of money is that improving the quality of money reduces the use of other real productive resources employed in the task of gathering information about relative values and conducting transactions and, therefore, increases the productive potential of the economy. That is, instead of being a supplement to other productive resources, money that is more stable liberates such resources from being employed in activities associated with uncertainties that exist when the purchasing power of money is unstable. When the form of money available in the economy is not reliable-that is, its purchasing power over time is not stable-some of other resources will be employed in dealing with the uncertainties. As monetary policies to stabilize the currency start to become effective and credible, other resources can be redeployed in more productive ways. In the end, the productive potential of the economy is greatest when the fewest of other resources are utilized in performing tasks for which money is intendedgathering information about relative values and conducting transactions.

From this analysis it should be clear that a monetary shock - an unanticipated change in the availability of money-would reduce the potential output of the economy. That is because the actions taken by businesses and households to readjust their actual money balances to desired levels will cause unavoidable changes in relative prices and the average level of all prices and, thus, introduce uncertainty into the economy. Naturally, such increased uncertainty causes resources to be committed to hedging, arbitrage, and speculation. Furthermore, since the quality of price information is diminished, mistakes will be made in interpreting signals about real demands for, and supplies of, goods and services. Overproduction of some things and underproduction of other things will mean that society's well-being is less than it could be.

Resources flow to their highest-valued uses only when the changing prices of things reflect shifts in fundamental real demands for, and supplies of, goods, services, and productive resources. Monetary disturbances introduce price changes that mask these fundamental forces. Consequently, excess production of some things and shortages of other things can occur simultaneously.

In a world with stable population and a given set of goods and services where no new products are invented, one would expect the money prices of final goods to gradually decline at the same pace as the improving productive efficiency of the economy's resources. The gains in wealth to the society from the higher productivity would be distributed to inhabitants in the form of "higher real incomes." That is, their unchanged money incomes would gradually command a larger basket of goods as increased availability of goods and services pressed down on money prices. This "productivity norm" (Selgin, 1990 and 1997) for the average of money prices can be thought of as a static baseline for the purchasing power of money: It would tend to rise in an expanding economy. It neglects population growth, labor force participation rates, introduction of new products, external trade, and distortions arising from tax structures and regulation. Nevertheless, it describes how people in an economy benefit from a stable currency. ${ }^{6}$

\footnotetext{
6 "An increase in the quantity of goods produced...must bring about an improvement in people's conditions. Its consequence is a fall in the money prices of the goods... But such a fall in money prices does not in the least impair the benefits derived from the additional wealth produced...But one must not say that a fall in prices caused by an increase in the production of the goods concerned is the proof of some disequilibrium which cannot be eliminated otherwise than by increasing the quantity of money" (Mises, 1949, p. 431).
} 
It is important to note that a condition of "rising purchasing power of money" is most commonly described by the pejorative "deflation." This unfortunate custom has caused most observers to believe that a gradually falling "price level" is as bad, or even worse than, a gradually rising "price level." Our analysis concludes there can be-and historical experience has demonstrated-"virtuous deflations" during periods of rapidly rising productivity. ${ }^{7}$

\section{Money and Innovation}

People can readily observe the effects of the introduction of new or better products: The money prices of old goods fall. The phenomenon is most obvious in examples such as computers. The availability of faster machines reduces the demand for, and therefore the prices of, slower models. The new availability of improved software, better fabrics, longer-lasting tires, compact disks with more capacity, and so on is accompanied by lower prices of the products they replace. But, if radial tires are cheaper and last longer than the bias tires they replace, it means people are richer as their incomes will acquire a higher standard of living. That, in turn, means they can consume more of something else. The increased demand for other things that is made possible by the availability of cheaper tires means the money prices of other things will be higher. Thus, while prices are not stable, the role played by money is unchanged. That is, the value of money can be stable even though the money prices of things must be changing in an expanding economy.

As is the case with increased efficiency in producing existing products discussed above, the benefits of greater wealth influence prices in two ways: (i) lower prices of less desirable older products and (ii) higher real incomes as a consequence of the lower prices of the goods that are superseded, allowing greater demand for-and higher prices of-other goods. If the pace of innovation is rapid and totally new products as well as improved products are introduced very frequently, the pace of obsolescence of old prod-

\footnotetext{
7 For more discussion of types of deflations, see Federal Reserve
} Bank of Cleveland (2002). ucts must also be rapid. In such a regime, one would expect to see frequent and significant declines of not only the prices of the inferior products but also the capital stock that produces them. That is, "creative destruction" implies falling prices of both goods and productive assets that are superseded by superior products. If such is not observed, it is evidence that the purchasing power of the currency is not stable.

\section{Countries and Monies}

There are many currencies in the world today-more than 100 . There are only a few standards of value-fewer than a dozen. A hundred years ago there was only one standard of valuegold-but already many national currency units. A dominant trend of the past century was the proliferation of national currencies, especially as new nation-states emerged from the breakup of the colonial empires and the Soviet Union. It seemed that one criterion of nationhood was a national currency. That trend may well have been reversed as the century ended.

The dominant monetary system among colonies was one that relied on currency boards for establishing monetary stability (Schwartz, 1993). The newly formed nations, however, abandoned the currency-board system for a number of reasons. Currency boards lost their standing as valuable institutions for establishing monetary stability after World War II because of the dramatic change in conventional intellectual beliefs, especially the erosion of the legitimacy of imperialism. Perhaps more significant, however, was the prevailing belief that a central bank, with discretion, would outperform a rule-bound currency board.

Aside from national pride, the idea that a nation-state should have its own currency and independent monetary policy was intellectually supported by the idea that some positive rate of inflation was optimal. Even when economists would not defend deliberate debasement of the currency, authorities often rationalized inflation on grounds of political necessity, especially in the face of often large and growing national debts. The political expediency of the "unlegislated tax of inflation" seemed for a while to have had a near universal appeal. Over time, the political benefits 
of deliberate inflation have been counterbalanced by financial innovations in domestic and global markets. In fact, the balance appears now to have shifted such that the costs associated with rising inflation outweigh any residual benefits. First central bankers, then ministers of finance, and finally politicians generally are finding that a reputation for tolerance of inflation is undesirable.

Twenty-five years ago, it was fairly common to hear even prominent, well-respected economists argue the merits of a weak external value of the national currency (devaluation) in order to gain some presumed competitive advantage over trading partners. Such notions now seem increasingly quaint. It is now unimaginable that a politician anywhere would achieve success by arguing that accelerating inflation and a weak currency would benefit local constituents. Much of what has happened in recent years perhaps reflects the rise in so-called "financial market vigilantism," which imposes a level of discipline not anticipated years ago.

Neither monetary sovereignty nor independent monetary policy is deemed to be worth very much in today's global financial markets. Moreover, seigniorage is quite small in a noninflationary world. Hence, it is becoming more widely understood that any net benefits associated with maintaining a national central bank and a national currency are quite small. Increasingly, the behavior of businesses and households around the world has included the pragmatic adoption of standards of value that serve their purposes irrespective of national origin. For a couple of decades, the people of the former Yugoslav republics used the Deutsche mark as their preferred monetary standard for the same reason that people in many countries around the world use the U.S. dollar. A reputation for stability of purchasing power means more to the consumer than the local content or national origin of the currency. As we have seen in the case of consumer goods, when the barriers to the free importation and use of products and services of superior quality are removed, people pragmatically choose quality and performance over patriotic gestures.

Reflecting these forces, the importation of monetary policy from another country has been a growing trend in recent years. Just a few years ago, 11 sovereign countries of Western Europe implemented their plan to shift monetary policy decisionmaking from the autonomous national central banks to a newly created supranational central bank and phased out the 11 national currencies in favor of a single monetary standard to be used by all. Soon other countries started giving up any notions of monetary autonomy and a national currency. Ecuador and El Salvador are examples of countries that have joined others in unilaterally adopting the U.S. dollar as their official standard of value.

\section{GOVERNMENTS AND MONEY}

We do not pretend, that a National Bank can establish and maintain a sound and uniform state of currency in the country, in spite of the National Government; but we do say that it has established and maintained such a currency, and can do so again, by the aid of that Government; and we further say, that no duty is more imperative on that Government, than the duty it owes the people, of furnishing them a sound and uniform currency.

—Abraham Lincoln (1839)

Abraham Lincoln connected sound banking with political liberty, affirming that government has both the ability and the obligation to provide a stable currency. His belief in the importance of a sound currency has been shared by most thinkers for the past 250 years. Lincoln's view that government would actually provide a stable currency, however, has enjoyed less acceptance. Skepticism about the government's role with regard to money has been the dominant view since the founding of the republic. These doubts are well summarized by the prominent twentieth-century economist Ludwig von Mises:

Whatever a government does in the pursuit of aims to influence the height of purchasing power depends necessarily upon the ruler's personal value judgments. It always furthers the interests of some people at the expense of other groups. It never serves what is called the commonweal or the public welfare. (Mises, 1949, p. 422) 
Constitutional forms of government usually specified a stable currency, but as James Buchanan observed, such provisions have been inadequate:

This framework role for government also was considered to include the establishment of a monetary standard, and in such fashion as to insure predictability in the value of the designated monetary unit. (It is in the monetary responsibility that almost all constitutions have failed, even those that were allegedly motivated originally by classical liberal precepts. Governments, throughout history, have almost always moved beyond constitutionally authorized limits of their monetary authority.) (Buchanan, 1994, p. 4)

\section{Debates about Money}

History is unfortunately replete with examples of governments trying to print money in order to finance their expenditures. Friedrich von Hayek, winner of the 1974 Nobel Prize in Economic Sciences, puts it this way: "History is largely a history of inflation, and usually of inflations engineered by governments and for the gain of governments" (1976, p. 29). In recent times, the hyperinflation of Germany in the 1920s and of Bolivia, Argentina, and Brazil in the 1980s are all examples of governments debasing their currencies and engaging in what Mises called "a fraudulent attempt to cheat the public" (1949, p. 782).

Until the second half of the twentieth century, there was little disagreement that a stable currency was best; the debate centered on how to provide it. Following World War II, the notion that some inflation might be desirable (or at least should be tolerated) entered debates about public policy for a relatively short time. But, after painful inflation experiences in the 1960s and 1970s, the question of whether to eliminate inflation is no longer widely debated.

In the closing years of the millennium, the problem of how to provide a stable value of money regained prominence. Alternative approaches to stabilizing currencies were pursued around the world, and public-policy debates returned to this issue because people were rethinking the role of government in their societies. The monetary institutions likely to appear during the twenty-first century will reflect the dynamic economic and political processes currently at work. It remains to be seen whether nations achieve and maintain stable currencies because of government, as Abraham Lincoln believed, or in spite of government, as thinkers as diverse as James Madison, Mises, and Hayek contended.

The sentiment that government powers should be constrained by constitutional design is certainly not unique to the monetary arena. For example, James Madison set forth principles of government that underscore his views on money. In his elaboration of the "rule of law," he comments, "To trace the mischievous effects of a mutable government would fill a volume" (Madison, 1977 [1788]). His doubts about elected representatives' ability to provide a stable currency are reflected clearly in his adherence to a specie (gold or silver) standard. Madison's defense of an exclusive role of Congress boils down to a distrust of populist sentiments: "A rage for paper money, for an abolition of debts, for an equal division of property, or for any other improper or wicked project, will be less apt to pervade the whole body of the Union than a particular member of it" (Madison, 1977 [1787]).

The history of money over the past two centuries shows the world groping for different institutional structures that limit governments' temptations to debase money in order to satisfy some short-sighted political objectives. The approaches used in the past have been functions of the nature of money prevailing at the time and of societies' views about the proper role of government. The approaches used in this century will surely be different from those of the past two if either of these two factors changes materially. In particular, while government will surely have some responsibility in providing a stable currency, government's exact role should not be taken for granted.

Historical Views of Money. Adam Smith defined the role of money as a medium of exchange, describing it as "the great wheel of circulation" (Smith, 1976 [1776], p. 309). However, money functions in at least two other ways: as a store of value and as a standard of value (unit of account). When we hold money, we trust that it will largely maintain its worth. If the value 
of currency is allowed to erode under conditions of inflation, the ability of money to serve as a store of value is seriously hampered. As a unit of account, money serves as a measuring stick, telling us how many units of something exchange for a unit of money. ${ }^{8}$

An often-overlooked consideration is that, while money is an integral part of society because of its service of these three roles, it is not desired for its own sake. Smith pointed out:

No complaint, however, is more common than that of a scarcity of money. Money, like wine, must always be scarce with those who have neither wherewithal to buy it, nor credit to borrow it... It is not for its own sake that men desire money, but for the sake of what they can purchase with it. (1976 [1776], pp. 458-60)

This confusion between more money and more purchasing power has contributed in large part to the pervading lack of trust in the provision of money by government. As Mises suggests, governments are often tempted to answer the cry for more purchasing power by simply creating more money. But in so doing, the opposite effect is achieved-the purchasing power of money is actually reduced. The result, as Alchian and Allen explain, is inflation: "a rise in the number of dollars required to purchase a given standard of living” (1977, p. 484). If inflation makes individuals uncertain about what to ask or what to give for goods or services, then the quality of money deteriorates, reducing its effectiveness as a medium of exchange. Money is no longer either an efficient store of value or an efficient unit of account, because this "ruler" with which we make our measurements is continually changing.

Three points are clear. First, inflation is highly undesirable. Second, governments have incentives to abuse their power of mintage, which, coupled with historical experience, has slowly created a

8 An appreciation of this role was evident in the thinking of Thomas Jefferson, who confided to a friend: "There is, indeed, one evil which awakens me at times, because it jostles me at every turn. It is that we have now no measure of value. I am asked eighteen dollars for a yard of broadcloth, which, when we had dollars, I used to get for eighteen shillings; from this I can only understand that a dollar is now worth two inches of broadcloth, but broadcloth is no standard of value. I do not know, therefore, whereabouts I stand in the scale of property, nor what to ask, or what to give for it" (1819). consensus among citizens that they cannot trust their governments with unfettered control over money. Third, the mechanisms people have contrived to protect themselves from the seemingly arbitrary debasement of currency have varied over time.

The Gold Standard. For most of recorded history, governments have taken some role in providing money to the economy. In early times, that role was limited to "authentication," verifying that coins contained the indicated metals. Even in historical monarchies, however, the authorities would occasionally lie to their people about money. People's dual reliance on, and distrust of, government with regard to the value of money is an age-old phenomenon. The view that, despite all contrary assurances, governments will eventually abuse their powers as counterfeiters led countries to develop institutions aimed at limiting a government's ability to print additional money. One such method was the gold and silver standards followed (on and off) by most countries from 1821 to 1973.

Specie-backed currency took money out of immediate government control. For example, if the dollar were defined as equal to $1 / 20$ of an ounce of gold, then the number of dollars that the United States could issue would be constrained by its holdings of gold reserves. Moreover, if Britain then defined its currency as to equal 5/20 of an ounce of gold-as it did before World War I-the exchange rate would be fixed at $\$ 5$ per pound. If either government issued more currency than prescribed by its gold standard-say, to finance a budget deficit-it would lose gold reserves to the country with the more stable currency. In this way, gold strengthened a government's covenant with its public not to erode the purchasing power of its money.

The unfortunate problem with a specie standard was that the value of money was only as stable as the value of the specie backing it. This led Benjamin Franklin to note that because "silver itself is of no certain permanent Value, being worth more or less according to its Scarcity or Plenty, therefore it seems requisite to fix upon something else, more proper to be made a Measure of Values" (1729; italics in original). Although a specie stan- 
dard could clearly result in undesirable swings in the purchasing power of money, the costs of having a fiat currency were thought to be even higher. In a letter to a friend, Madison stated:

It cannot be doubted that a paper currency, rigidly limited in its quantity to purposes absolute necessary, may be equal and even superior in value to specie. But experience does not favor reliance on such experiments. Whenever the paper has not been convertible into specie, and its quantity has depended on the policy of the Government, a depreciation has been produced by an undue increase, or an apprehension of it. (Madison, 1820)

Later, commenting on a "Report on a State's Bank," Madison wrote, "But I am not yet weaned from the opinion long entertained, that the only adequate guarantee for the uniform and stable value of a paper currency is its convertibility into specie" (1831; emphasis added). Repeating his view that a stable paper currency is theoretically possible, doubts remained: "But what is to ensure the inflexible adherence of the Legislative Ensurer to their own principles and purposes?" (1831). Madison left no doubt about what is essential: a money that has stable value. His doubts about the people's elected representatives providing a stable currency are reflected clearly in his adherence to a specie standard, especially given his recognition that paper money supplied by an honest government is superior to a specie standard.

The quantity theorists of the late nineteenth century, John Stuart Mill and Alfred Marshall, also believed that, although a gold standard provided undesirable swings in currency value, it was the only way for governments to provide a stable paper currency. Mill observed:

After experience had shown that pieces of paper, of no intrinsic value, by merely bearing upon them the written profession of being equivalent to a certain number of francs, dollars, or pound... governments began to think that it would be a happy device if they could appropriate to themselves this benefit... The only question is, what determines the value of such a currency...We have seen, however, that even in the case of metallic currency, the immediate agency in determining its value is its quantity... The value, therefore of such a currency is entirely arbitrary. (Mill, 1907; emphasis added)

Citing the nineteenth-century economist, William Jevons, Mill asserts, "so that the relation of quantity to uses is the only thing which can give value to fiat money." That being the case, Mill thought that convertibility (to metal) was the only thing to prevent temptation to "depreciate the currency without limit” (Mill, 1907).

For the first 195 years following the Declaration of Independence, most government paper currencies were linked to specie. The U.S. dollar was defined in terms of a weight of gold (or occasionally silver). However, this did not completely restrain governments from manipulating the value of their currencies. First, in order to generate revenue, countries would frequently abandon the gold standard during times of war. Second, even without officially abandoning gold, countries could and did periodically redefine the value of their currencies in terms of gold. Instead of allowing gold or foreign reserves to consistently drain from their coffers, they would "be forced" to devalue their currency.

At first glance, it would appear that a gold standard provided no real discipline if countries could devalue their currencies at will. The discipline came from the fact that countries actually could not do so without suffering a cost. If there was a threat that a country would devalue its currency, massive speculative attacks would ensue as investors attempted to shed themselves of that currency. The devaluing country would eventually lose massive amounts of foreign reserves (gold and foreign currencies). Over 1966 and 1967, for instance, Britain lost nearly 28 million ounces of its gold reserves defending its currency and, on a single day, November 17, 1967, lost reserves valued at more than $\$ 1$ billion.

The common wisdom is that the frequency and destabilizing effects of such attacks caused the Bretton Woods system, and thus the last vestige of a gold standard, to be abandoned in 1973. While this is correct on a superficial level, the underlying cause was that, despite the threat of speculative attacks, governments around the world were unwilling to do what was necessary to maintain 
a stable currency-namely, to limit the supply of fiat money. Mises was blunt in his condemnation of deliberate, governmentally engineered devaluations of currency, and his criticism of the stated as well as the unstated objectives of a devaluation policy are as relevant today as when he wrote Human Action over 50 years ago: "It is impossible to take seriously the arguments advanced in favor of devaluation" (1949, p. 790).

\section{Alternative Monetary Arrangements}

Separation of the Central Bank and the

Treasury. Another way to keep governments "honest" is to remove the power to inflate from those with the most incentive to inflate. This is achieved by making the central bank-which has the power to inflate-highly independent of the Treasury-which has the incentive to inflate. This institutional structure is not a panacea but has proven especially useful: Studies have shown that countries where central banks are more independent have lower inflation rates on average (Alesina and Summers, 1993).

The high-inflation era of the 1970s showed us what countries unfettered by fixed exchange rates and a dollar convertible into gold will do left on their own. Addressing this deficiency, the U.S. Congress passed House Concurrent Resolution 133 in 1975, requiring the Federal Reserve to announce annual targets for monetary growth rates. In 1978, the Full Employment and Balanced Growth (Humphrey-Hawkins) Act was passed, requiring the Federal Reserve to explain these objectives and any deviations from them.

Most major central banks experimented with this form of "instruments monitoring" in the 1970s and 1980s, establishing growth rates for various money measures in an effort to put boundaries on the rate of inflation.

Despite the relatively low inflation rates realized by most industrial countries around the world since 1983, the call for further institutional constraints on central banks is growing. One example is legislation enacted by New Zealand and other countries that the sole objective of central banks is to provide price stability.

Currency Boards. An institutional constraint that has been adopted by smaller countries that lack an established reputation for low inflation is the currency board, similar to those initially adopted by former colonies. The central idea behind currency boards is to look more seriously at the discipline provided by fixed exchange rates. For example, in order to maintain a fixed exchange rate between a small country and the United States, the small country's monetary policy must, in essence, be dictated by the United States. If the United States has the credibility to maintain low inflation, the hope is that the country with the currency board will also achieve credibility over time.

Currency boards are much like a small-scale version of Bretton Woods except that there is no longer a link between the dollar and gold to guarantee that the United States will follow a policy of low inflation. Currency boards are probably best described as small boats anchoring themselves to a large ship. Because the large ship is not firmly anchored, the small countries are left hoping that rough seas will not cause the large ship and, thus, the small boats to drift too far off course.

Private Currencies. Perhaps the most interesting mechanism by which a stable currency might be achieved was proposed by Hayek (1976) in Denationalisation of Money (see also Friedman and Schwartz, 1986). Although central banks, currency boards, and the gold standard each attempt to restrain a government's tendency to inflate, Hayek suggested that governments be removed altogether from the provision of money. He contended that if private currencies are allowed to circulate freely, competition will ensure that the value of these currencies will remain constant. If any issuer attempts to collect too much seigniorage by printing excessive amounts of its currency, consumers will substitute out of that currency into a competing currency with a more stable purchasing power. The offending currency will cease to circulate as money. Thus, currency issuers will have an incentive to remain honest.

Writing almost 30 years ago, Hayek was clearly ahead of his time. His proposal that governments be completely removed from the business of issuing money is not likely to come to fruition in the near future. Nevertheless, his basic propo- 
sition that competition will provide the necessary incentive to keep people (or countries) honest is relevant today. International currencies are increasingly competing to become the currency of choice. The rapid "dollarization" or "euroization" in central Europe, the former Soviet Union, and Latin America shows how a foreign currency can become a legitimate substitute for a domestic currency that has failed to maintain its value. Paradoxically, it may be the end of fixed exchange rates and the flawed discipline provided by that system that have allowed internationally competing currencies to flourish.

Recent history teaches us that Hayek was correct when he pointed out that

\begin{abstract}
Gresham's law will apply only to different kinds of money between which a fixed exchange rate is enforced by law. With variable exchange rates, the inferior-quality money would be valued at a lower rate and, particularly if it threatened to fall further in value, people would try to get rid of it as quickly as possible. The selection process would go on towards whatever they regarded as the best sort of money among those issued by the various agencies [or countries], and it would rapidly drive out money found inconvenient or worthless. (Hayek, 1976, p. 31)
\end{abstract}

\section{Money, Taxes, and Deficits}

Governments impose taxes on people in a variety of ways but always on nominal money prices and incomes. Consequently, debasement of the currency always generates greater nominal tax revenue for the taxing authorities. When tax structures are progressive and not indexed, real tax revenue rises when the average of money prices of things rises-the value of a currency erodes. Furthermore, much of the debt of governments is fixed in nominal money units. Thus, debasement of the currency works to the advantage of the governmental taxing and spending authorities. Government's command over the economy's output rises while the government's creditors are repaid with reduced purchasing power. The effect of these institutional arrangements is that the relative share of the economy absorbed by the government increases when the purchasing power of a currency is declining.
Governments usually require that people's tax liabilities be disposed of by remitting liabilities of the central bank to the account of the Treasury at the central bank. When governments incur deficits and issue debt, they are giving to security holders the promise that they (or their successors) will raise sufficient tax revenue in the future (or issue new bonds) to repay the borrowed sums. At times, the issuance of the debt instruments of the government (increased supply of securities) causes at least temporary downward pressure on security prices (higher interest rates). If the policy of the central bank is to maintain a fixed level of market interest rates and accommodate all demands for credit at that rate, the central bank will passively expand its balance sheet-issue greater quantities of currency and bank balances. Without any corresponding increase in the public's desire to hold greater balances, the excess creation of liabilities of the central bank will result in a bidding up of the money prices of goods, services, and other financial assets. This dynamic has been common even when the central bank is prohibited from directly purchasing the newly issued debt instruments of the government.

\section{Root Demands for Fiat Monies}

As noted above, people throughout the world use U.S. dollar notes in everyday commerce even though their own governments also furnish a currency. They use the U.S. currency even when it is illegal to do so. If asked why they do so, they will say it is simply because the value of the dollar is more stable than other currencies. Two questions arise: Why isn't the domestic currency stable, and why is the value of the dollar more stable? Both are fiat currencies, that is, their value is not defined in terms of something else, such as gold. Both may be legal tender in the home country, but the U.S. dollar is legal tender in only a few countries outside the United States.

So, why do money prices rise more rapidly in terms of one currency than the other? The answer can only be that some monetary authorities create new units of their currency at a rate that is faster, relative to demand to hold it, than other monetary authorities do. Clearly, if the 
amount of money people want to be holding is always exactly the amount there is, the purchasing power of the currency can be neither rising nor falling. A disturbance to this happy situation can occur one of three ways: (i) people decide to hold less (more) of the currency and the process of ridding themselves of the excess (or acquiring larger balances) causes money prices to adjust; (ii) monetary authorities create money units at faster (slower) rates than people want to add to their holdings; (iii) favorable or unfavorable surprises in the amount of things available to purchase (natural disasters, crop failures, bumper crops, etc.) cause changes in both relative prices and the average of prices because the society is richer or poorer.

The first possible disturbance-changes in people's desire to hold some of the currencyraises questions about what goes into a decision to hold any of a currency, especially if there is an alternative available. The most fundamental reason that inferior currencies continue to be held even though a superior alternative is available is that taxes must be paid to the domestic governments in units of the national currency. The necessity to remit tax receipts in the form of the liabilities of the national central bank ensures at least some transitory demand for the currency. Since there is a demand, it would be possible to constrain the supply so that there is neither an excess nor a deficient supply relative to the demand. The reason most, if not all, prices of things in terms of that currency rise is that the monetary authorities do not constrain the new supply to match the demand exactly. The usual reason they do not do so is that the government commits to disburse funds to people in amounts that are greater than the sum of tax receipts and proceeds from debt issuance.

\section{Introduction of New Monies}

There has never been a "phoenix-like" currency. ${ }^{9}$ Because the central role of money is mini-

\footnotetext{
9 "The acceptance of a new kind of money presupposes that the thing in question already has previous exchange value on account of the services it can render directly to consumption or production. Neither a buyer nor a seller could judge the value of a monetary
}

mization of information and transaction costs, people will not use an entity as money, a medium of indirect exchange, if they have no prior experience upon which to base their expectations about the prices of things expressed in terms of the proposed money. Historically, then, new claims to money (i.e., money substitutes) had to circulate for a period of time sufficiently long to establish a "track record" in the minds of people. Warehouse receipts (such as gold certificates) were an early type of paper claims to money that evolved into paper fiat monies.

As described above, U.S. dollars were originally defined to be (and convertible into) specified amounts of gold. For domestic purposes, dollars became a fiat currency in 1933 when the government made it illegal for American residents to own gold. Nevertheless, for official, international payments made by one government to another, dollars continued to represent claims to gold until the early 1970s. For the past three decades, dollars have been simply the liabilities of Federal Reserve Banks.

In the second half of the twentieth century, numerous currencies have been introduced by governments. In every case, the new entity was initially defined in terms of a known medium of exchange. After World War II, the German

Deutsche mark was defined to be worth $1 / 4$ of a U.S. dollar and the Japanese yen was introduced as 1/360 of a U.S. dollar at a time the dollar was still defined as 1/35 of an ounce of gold. For over 25 years these currencies were claims to dollars and, indirectly, to gold.

Newly liberated countries in the final decade of the twentieth century introduced new currencies but always defined in terms of, pegged to, and convertible into other familiar national currencies, such as U.S. dollars, Deutsche marks, British pounds, or yen. When the domestic experience with a currency has been favorable for sufficiently long that confidence about future purchasing

unit if he had no information about its exchange value-its purchasing power-in the immediate past...A medium of exchange without a past is unthinkable. Nothing can enter into the function of a medium of exchange which was not already previously an economic good and to which people assigned exchange value already before it was demanded as such a medium” (Mises, 1949. pp. 411, 426). 
power is high, governments have chosen to delink (float) their nation's money relative to foreign currencies.

\section{CENTRAL BANKS AND MONEY}

\section{The Tools of Monetary Policy}

The tools available to central banks to influence the purchasing power of their currency are quite few. Since it is their own liabilities that serve as money, altering the size of the central bank's balance sheet is the essential monetary tool. The assets of the balance sheet usually include loans to banking companies and securities that may be denominated in either the domestic currency or a foreign currency. In either case, the securities are mostly the obligations of the domestic or a foreign government. Central banks can, if they choose, control the size of their balance sheets very precisely. That being the case, they can unilaterally determine the supply of central bank money. The demand for central bank money has several sources: Domestic (and maybe foreign) households and businesses have a demand for the notes issued by the central bank; and commercial banking companies (and maybe others) hold reserve or clearing balances at the central bank, based on their business needs or legal reserve requirements.

Since there is a demand for money from the central bank and the potential to control the supply, monetary policies to stabilize the value of the currency are possible. The difficulty is in estimating the demand by people to hold central bank money. The domestic public's desire to hold notes issued by the central bank tends to grow in proportion to incomes, although changes in the forgone interest from investments can influence currency demands (higher market interest rates mean you hold less cash). Also, the commercial banks' demand for balances at the central bank is a derived demand. The public's demand for checking-type accounts and other reservable deposits at the financial intermediaries determines the amounts of balances held at the central bank. If some liabilities of banks, but not others, are sub- ject to legal reserve requirements, shifts in the public's preferences between types of deposits will affect the derived demand for balances at the central bank. Similarly, if different sizes or types of financial intermediaries are subject to different legal reserve ratios, shifts in deposit balances among the institutions will affect the derived demand for central bank balances. In other words, institutional arrangements affect the difficulty or ease of estimating the demand for the liabilities of the central bank.

Where it is judged to be difficult to estimate the demand for central bank money, the monetary authorities typically target an overnight interest rate at which they passively accommodate increases and decreases in the demand for their liabilities. While that ensures that there can be neither an excess supply of nor an excess demand for central bank money on an overnight basis, it does not ensure secular ${ }^{10}$ stability in the purchasing power of the currency.

The public's desire to hold balances at the depository intermediaries is influenced by several factors-including the opportunity cost of forgone returns on alternative assets, ${ }^{11}$ domestic as well as foreign. This means changes in investment opportunities as well as consumption plans influence the balances desired by businesses and households. So, the changing yields on alternative savings and investment assets have an indirect effect on the demand for central bank liabilities. Depending on the source of these changing yields, the induced change in the outstanding stock of central bank money may or may not be consistent with maintaining stable purchasing power at the initial overnight bank rate.

Knowing the prevailing operating procedures of central banks is important for understanding the risk of unintended increases or decreases in the purchasing power of money. As mentioned above, it is common for central banks to target an

\footnotetext{
10 "Secular" means of, or relating to, a long term of indefinite duration.

${ }^{11}$ When the public holds money, they receive either no nominal return on their cash, or very little-less than could be earned on normal investments-on deposits in banks. It is in this sense that we speak of there being an "opportunity cost" of holding money (instead of holding interest-bearing investments).
} 
overnight interbank rate: The operating desk of the central bank buys and sells (in the market) securities previously issued by the government. A purchase of securities by the central bank increases $^{12}$ the supply of central bank liabilities while a sale of securities reduces the supply. In effect, the operating desk sets a price at which it is willing to buy (sell) securities from private holders-the central bank's demand for the debt instruments of the government is unlimited at that price (interest rate). If the market supply of securities to the central bank increases (the demand by private holders for such securities decreases), the quantity of central bank money will increase.

For example, if innovations in the economy raise the perceived returns on real productive capital (which can mean anything from better management to new machines), there will be a tendency for the interest rates offered on financial instruments to rise as well. ${ }^{13}$ There will be both an increase in the demand for loanable funds (money borrowed from a bank) and a decrease in the demand to hold fixed-rate instruments such as government securities. The higher return on financial assets means a higher opportunity cost of holding bank notes or low-yielding balances in banks. This will foster a decline in the quantity demanded as people and businesses seek to reduce the amount of money they hold. Other things being held the same, if the central bank's operating procedure involves pegging a nominal overnight interest rate, the marketplace forces pressing down on security prices (up on interest rates) will be met by an expansion in the stock of central bank money, even though the amount of money demanded is declining!

Temporarily, the expansion of the supply of central bank money reduces the upward pressure on market interest rates even though an excess supply of money has been created (increased

\footnotetext{
${ }^{12}$ When the central bank purchases a security from the general public (usually a bank), it pays money for the security. This money is a liability of the central bank, an increase in money held by the public, and, of course, a reduction in the number of securities held by the public.

${ }^{13}$ Higher expected rewards to real productive capital cause people to buy more of the new productive assets. As they do so, they seek to reduce their holdings of old financial assets. This will cause the price of the old assets to fall, which in turn raises their yield.
}

supply and falling quantity demanded). Under such circumstances, the excess supply of such monies will cause purchasing power to erode as the weighted average of money prices that are rising will exceed the weighted average of prices that are falling. The adjustment process-inflation-will continue (i) until the returns on real productive capital fall to the initial lower level or are brought down to that level by the inflation tax or (ii) until the central bank raises the pegged level of the overnight bank rate to the point where the amount of central bank money demanded is the amount outstanding.

Conversely, if diminished economic prospects are reducing perceived yields on productive capital-or are causing a general preference for more liquidity in the form of secure bank deposits and other low-risk financial instruments-security prices will be bid up (market interest rates will be bid down) and the lower forgone yields will cause people to try to increase their holdings of bank deposits and currency. That means greater demand for central bank money; but the only source is the central bank. If the monetary authorities do not correctly analyze these fundamental economic forces and they fail to lower the nominal overnight intervention rate, the operating desk of the central bank will be selling (or buying fewer) securities and the central bank balance sheet will shrink (supply goes down) or grow too slowly at a time when the amount of central bank money demanded is rising. In time, the weighted average of money prices that are falling will exceed the weighted average of prices that are rising until people want to hold balances that are consistent with the amount of central bank money in circulation. This process, deflation, results in a general rise in the purchasing power of money.

The critical element, then, in the formulation of monetary policy actions is ascertaining the forces at work in the economy that are tending to press upward or downward on the structure of market interest rates, including the perceived yields on real productive capital. Since observed interest rates in a world of fiat money include an "inflation premium," market rates will change because people come to expect the average of money prices to rise at a faster or slower rate while 
the expected yields on real productive capital may be changing simultaneously in the same or opposite direction. Sifting through the variety of forces at work is essential in making judgments about the appropriate level for the overnight bank rate when deciding on the prices at which government securities will be bought or sold. ${ }^{14}$

\section{Talking about Monetary Policy}

Popular usage by "Fed watchers" of the expression "monetary policy" is quite different from the way it is used in this essay. Even qualifiers such as monetary policy objectives and monetary policy actions usually require elaboration in order to be clear. At least one dictionary definition of policy is "a high-level overall plan embracing the general goals and acceptable procedures, especially of a government body." Yet, the most frequent references we see in the daily press about monetary policy include characterizations of policy as "tight" or "easy" or claims that the monetary authorities are going to "tighten" or "loosen" monetary policy. How can a "highlevel overall plan" be characterized as tight or easy? Maybe it is fair to characterize the actions to achieve the objectives as being "tighter" or "easier" (than previously?), but it certainly is not appropriate to talk about the objectives as being tight or easy.

Even the most avid "fine tuner" of monetary policy has a long-term objective in mind, and people who share the same objective may differ on the appropriate tactics to be successful. Excessive focus on the short-term actions to implement a policy runs the risk of confusing observers regarding the ultimate objective. If observers do not know the intended destination, or do not agree with the destination, they will naturally secondguess the appropriateness of course corrections.

If the ultimate objective is well understoodand agreed to-it is reasonable to hold policymakers accountable for actual results. Good intentions are not enough if the results are bad. However, the results can be judged as successful

\footnotetext{
${ }^{14}$ See the discussion of targeting interest rates in www.clevelandfed.org/Annual01/essay.htm.
}

or not relative only to what was intended. Without understanding and agreement about objectives, there is no way for accountability to be tied to performance.

The fact that there are long and variable lags before monetary policies take effect means that objectives must be stated in a multi-year context. ${ }^{15}$ If the time horizons of the policymakers and the observers differ, it may be difficult to get agreement on appropriate weights to give to any transition costs when compared with the benefits of progress toward achieving the ultimate objective. As a result, disagreements about the appropriateness of a specific policy action may reflect nothing more than differences in the preferred time path to the destination. All that gets lost in the familiar chatter about whether the policy action represents "tightening" or "loosening."

\section{The Formulation and Implementation of Monetary Policy}

The consumption behavior of households tends to reflect expectations about their longerterm ability to consume. This phenomenon has been called the life-cycle hypothesis, standard or standardized income, and, of course, by Milton Friedman, permanent income (Friedman, 1957). The basic idea is familiar. Transitory changes in measured income or cash flow fluctuate around some longer-term average; household consumption behavior does not fully reflect these transitory changes in the short run. Sharp increases in measured cash-flow income are not fully reflected in corresponding increases in current consumption; nor are sudden rapid declines in measured cash-flow income reflected in corresponding declines in consumption spending.

\footnotetext{
${ }^{15}$ The time it takes monetary policy to influence the other macroeconomic variables such as nominal and real output and the rate of change of prices is known as the lag. Sometimes the lag is short and sometimes it is long. It differs as a function of people's expectations. After a period of no inflation, people tend to interpret an increase in prices as temporary and not necessarily a permanent price increase. After a period of rapid inflation, they interpret an increase in prices as more inflation. How quickly people adjust to changes in policy is related to their experience and their underlying conception of why changes are taking place. It is in the sense that lags depend upon past experience and what people see as causing the changes that we say that policy lags are long and variable-depending on experience.
} 
Changing Productivity. Both the theoretical framework and empirical observations traditionally suggest that permanent income is relatively steady, while transitory changes in measured income are more variable. However, it can also be the case that periods of rising or falling productivity and changes in the pace of technological innovation produce a generalized perception that permanent income is rising or falling relative to measured or cash-flow income. People may come to form these expectations in a variety of ways.

Rising Productivity. Sustained periods of steady employment and growing paychecks may lead people to expect that not only has their real standard of living risen but that it will continue to rise in the future, possibly at a faster rate than previously expected. Or, they may come to expect fewer or shorter periods of unemployment. Or, they may observe that their $401 \mathrm{~K}$ savings plans or defined-contribution retirement programs now promise a higher future stream of income than previously thought. In a variety of ways, people come to expect that they will be able to consume more in the present, as well as in the future, than they previously thought.

As a result of any (or some combination) of these various forces at work in a "new economy," households perceive that their long-term ability to consume is higher. ${ }^{16}$ The availability of credit means that people can increase their spending in anticipation of the future increase in their incomes. This, in turn, means households will consume a greater share of their current measured income so, consequently, the contemporaneous personal saving rate will fall. Clearly, this analysis suggests that, in such an environment, a low or even negative saving rate is unavoidable and is not a problem to be addressed by economic policies.

In the business or entrepreneurial sector, rising productivity and an enhanced pace of technological innovation mean that the marginal efficiency of capital is higher. ${ }^{17}$ Consequently, in return for giving up consumption today, relatively more will

${ }^{16}$ In economists' jargon, they have moved to a higher indifference curve.

17 Again, in economists' jargon, the production possibility boundary has both shifted out and changed its shape. be available for consumption tomorrow. Real interest rates rise as new opportunities bring a higher rate of return on new business investment.

These higher real interest rates are not a matter of policy choice or of anyone's discretion. Rather they are a manifestation of economic forces that result in better uses for available productive resources. With households and businesses both increasing their claims on current productive resources, real interest rates must rise in competitive markets.

Gold Standard. Higher real interest rates need not imply higher nominal interest rates. Just to exclude complications for the moment, consider the case under a gold standard. Increased productivity growth and technological innovation in an environment of monetary stability implied by a gold standard means that the price level falls. That is, output of goods and services increases because of higher productivity but the quantity of money-gold-remains in relatively fixed supply. Thus, the purchasing power of money rises in the face of greater productivity. The falling price level means that greater permanent real income can be distributed to society with the same level of nominal income. The falling price level also implies that unchanged nominal interest rates, or possibly even lower nominal interest rates, correspond to higher real interest rates. These higher real rates are the essential market mechanism by which competition between consumers and investors rations present consumption against augmented future consumption. But, we're not on a gold standard.

Fiat Money. The alternative to commodity money, as we have seen, is "managed money," a discretionary monetary policy regime using a procedure that "pegs" the interest rate. The upward pressure on real interest rates that is a necessary consequence of greater productivity and the faster pace of technological innovation initially will put upward pressure on nominal, i.e., market, interest rates. Greater and greater injections of central bank money will then be necessary to keep the pegged level of the nominal overnight interbank rate unchanged. Rising market interest rates mean that the opportunity cost of holding money balances is rising. That, 
in turn, means the quantity of money demanded declines and the rate at which money changes hands increases as households and businesses seek to rid themselves of undesired money holdings. This combination of excess money holdings and the faster growth of central bank money means that a higher rate of nominal final demand growth would be accommodated by a more expansionary rate of money growth. Again, too much money chasing after too few goods. In such an environment, the increase in nominal interest rates, while initially reflecting upward pressure on real interest rates, would be augmented by a rising inflation premium. The overnight interbank rate would be under persistent upward pressure so long as it continued to lag behind market-determined interest rates.

This dynamic process describes an environment in which acceleration in the pace of technological innovation and productivity growth could inadvertently become an inflationary process. A central bank's actions to maintain an unchanged overnight rate would accommodate nominal price increases by failing to accommodate increases in the real interest rate. As a result, credit markets would be unable to play their role in rationing available real productive resources amongst heightened competing demands that reflect the increased return to real capital. Of course, this analysis is symmetric: A sustained deceleration of the pace of technological innovation and productivity growth would imply a fall in the equilibrium real rate and a necessity to reduce the central bank's intervention rate in order to avoid a procyclical downward thrust of monetary injections.

\section{Policy Neutrality}

In the analysis above, "real interest rates" refer to inflation-adjusted nominal interest rates, that is, anticipated yields on an investment after allowing for changes in the purchasing power of money. For example, the rate of inflation that is expected over the life of a bond is subtracted from the nominal yield to obtain the real yield.

Sometimes one hears or reads references to the "real federal funds rate" or "real overnight interbank rate." This makes no sense. Because there is no meaningful one-day inflation rate, there is no statistical measure of anticipated changes in the purchasing power of money in a single day that can be used to measure a real return for one day.

As an alternative to referencing "real interest rates," economists employ a concept of a "natural rate of interest." While this natural rate cannot be observed, the forces that would tend to cause cyclical or secular increases or decreases would include such factors as the changing productivity trends and pace of technological innovation discussed above. Sometimes the natural rate is associated with the average rate of real output growth over long periods. Demographic patterns, political and economic institutional arrangements, and even geopolitical developments will also influence this "natural" rate.

One thing that does not influence the natural rate is the overnight, interbank rate targeted by central banks. It is simply impossible for central banks to "push up" or "hold down" market interest rates. However, actions by the central bank to target an overnight intervention rate in the face of sometimes strong pressures at work on market interest rates have a major impact on the performance of an economy over time.

As defined above, a world without inflation is one in which people make decisions in the confident expectation that all observed changes in money prices of goods, services, and assets are changes in relative prices, and all observed changes in interest rates are changes in real rates. That is, the "inflation premium" in nominal interest rates is zero, so only those forces that influence the natural rate of interest are causing changes in market interest rates.

A neutral monetary policy would be one in which injections of liquidity by the central bank are faster or slower as necessary to maintain this non-inflationary environment. When forces are at work to raise the natural rate of interest, actions to peg the intervention rate at an unchanged level would require larger and larger injections of central bank money. However, as described above, in that same environment the quantity of money people want to hold idle is declining. Increasing supply and falling demand is not neutral. 
To remain neutral, the intervention rate targeted by the central bank must rise in concert with a rising natural rate. Likewise, if the pace of technological advance and productivity growth slows, it is necessary to reduce the intervention target rate in order to maintain the neutral stance. These dynamics show that changes in the targeted intervention rate cannot be taken as indications of the "tightness" or "easiness" of the thrust of policy. The mere observation that the announced target rate has been increased or decreased does not indicate that the stance of policy actions is more "stimulative" or "restrictive."

On the contrary, failure to change the target rate in concert with forces influencing the natural rate would mean that policy actions have become, de facto, more or less expansionary. The paradox, then, is that maintaining neutrality of the thrust of monetary policy actions requires changes in the announced target intervention rate as frequently as policymakers obtain information indicating that the natural rate of interest has risen or fallen.

\section{COMPETING CURRENCIES}

The concepts of competitive money, currency boards, and the independence of the central bank were no doubt far from the mind of Abraham Lincoln when he spoke of the government's obligation to provide a stable currency. However, these are a few of the mechanisms by which governments have tried to achieve this end. It must be remembered, however, that these different options are not independent.

The potential for the forces of competition that have served market economies so well to discipline a country's ability to print money freely is particularly promising. According to Hayek, "[i]t might prove to be nearly as difficult for a democratic government not to interfere with money as to regulate it sensibly" (1976, p. 74; emphasis added). He argues that countries around the world should abolish "any kind of exchange control or regulation of the movement of money between countries" and provide "the full freedom to use any of the currencies for contracts and accounting" (1976, p. 74). Further, there should be "the opportunity for any bank located in these countries to open branches in any other on the same terms as established banks" (1976, p. 17).

Laws could be changed in various ways in the United States to foster more effective competition. For example, federal law (Title 31, Section 5103) states that "United States coins and currency (including Federal Reserve notes...) are legal tender for all debts, public charges, taxes, and dues. Foreign gold and silver coins are not legal tender for debts." This law might be altered so that contracts written in terms of foreign or alternative domestic monetary units, including specie, could compete with dollars. Almost 30 years ago, the British House of Lords "ruled that in English courts, foreign creditors could now have their claims recognized in their own currencies" (The Financial Times, 1975).

Governments must have a role in the enforcement of contracts. As Mises observed in Human Action, the laws and courts of a country

$$
\begin{aligned}
& \text { define what the parties to the contract had in } \\
& \text { mind when speaking of a sum of money...They } \\
& \text { have to determine what is and what is not legal } \\
& \text { tender. In attending to this task the laws and } \\
& \text { the courts do not create money [emphasis in } \\
& \text { original]...In the unhampered market economy } \\
& \text { the laws and the judges in attributing legal } \\
& \text { tender quality to a certain thing merely estab- } \\
& \text { lish what, according to the usages of trade, was } \\
& \text { intended by the parties when they referred in } \\
& \text { their deal to a definite kind of money" [empha- } \\
& \text { sis added]. (Mises, 1949, p. 780) }
\end{aligned}
$$

Legislation requiring enforcement of "specific performance" by the courts would increase the opportunity for currency competition. Currently, in most countries of the world, when there is a dispute involving a contract that is stated in terms of a currency or unit (such as gold) other than the national currency, courts will not require performance in the stated unit but will require that an "equivalent payment" in the national currency be paid.

Money in the twenty-first century will surely prove to be as different from the money of the past century as that money was from that of the nineteenth century. Just as fiat money replaced specie-backed paper currencies, electronically initiated debits and credits will become the dom- 
inant payment modes, creating the potential for private money to compete with government-issued currencies. Such competition between private and governmental monies may help countries around the world to finally live up to Lincoln's challenge of fulfilling "the duty [government] owes the people, of furnishing them a sound and uniform currency."

\section{SUMMARY}

Stable money enhances growth. Whenever the purchasing power of money is falling (the impact on the weighted average of all prices from those that are rising exceeds that of those that are falling) productivity improvements are smaller. The faster the average of prices rise, the slower the productivity improvements. This result is unavoidable because the changes in money prices of goods and factors of production do not accurately reflect changes in relative values. Consequently, businesses and households make mistakes that they would not have made if they could be confident that all observed price changes are the result of shifts in the supply of, or demand for, some things rather than other things. Furthermore, when the value of money is not stable, changes in interest rates are not necessarily changes in real interest rates. To the extent that changes in interest rates reflect uncertainty about the future purchasing power of money, mistakes in the allocation of resources occur.

The most common forms of money in use in the world today are the liabilities of central banks. The almost universal requirement that taxes be paid to governments in the form of the liabilities of a central bank ensures that there is a demand for such liabilities. However, to some extent the demand for central bank liabilities is a derived demand, dependent on people's usage of the liabilities of financial intermediaries such as banks. Institutional arrangements such as interest prohibitions or ceilings and idle reserve requirements can affect the demand for central bank liabilities, making the amount demanded at any time difficult to estimate.

Central banks control the supply of central bank money by acquiring or disposing of securi- ties, usually those issued by a sovereign government. In effect, central banks choose levels of nominal interest rates at which they have a horizontal demand for the liabilities of the government. If they guess correctly, the rate at which private holders supply securities to the central bank will generate additional central bank liabilities at the same rate as businesses and households desire to add to their holdings (indirect in the case of "inside money," the deposit liabilities of financial intermediaries). The value of money is stable when there is neither an excess supply of nor an excess demand for the liabilities of the central bank.

When the public's supply of securities to the central bank changes, the growth rate of central bank liabilities also changes. If the public's demand (direct and indirect) for central bank liabilities is not changing in the same direction and by the same amount, the average purchasing power of money (the weighted average of the prices of goods and services) will rise or fall as people seek to dispose of excess, or acquire additional, obligations of the central bank. Such adjustments alter relative prices and induce resource reallocations! Unavoidably, then, output potential is temporarily reduced. Maximum output—and highest standards of living-is achieved only when the purchasing power of money is stable.

\section{REFERENCES}

Alchian, Armen. "Why Money?" Journal of Money, Credit, and Banking, February 1977, 9(1, Part 2), pp. 133-40.

Alchian, Armen and Allen, William R. Exchange and Production: Competition, Coordination, and Control, 2nd ed. Belmont, CA: Wadsworth Publishing, 1977.

Alesina, Alberto and Summers, Lawrence H. "Central Bank Independence and Macroeconomic Performance: Some Comparative Evidence." Journal of Money, Credit, and Banking, 1993, 25(2), pp. 151-62.

Brunner, Karl, and Meltzer, Allan H. "The Uses of Money: Money in the Theory of an Exchange 
Economy." American Economic Review, December 1971, 61, pp. 784-805.

Buchanan, James M. "Notes on the Liberal Constitution.” Cato Journal, Spring-Summer 1994, 14(1), p. 1-9; see p. 4.

Federal Reserve Bank of Cleveland. "Governments and Money.” 1995 Annual Report, 1995; www.clevelandfed.org/annual/essay.htm.

Federal Reserve Bank of Cleveland. "Theory Ahead of Rhetoric: Economic Policy for a 'New Economy'., 1999 Annual Report, 1999;

www.clevelandfed.org/Annual99/theory.htm.

Federal Reserve Bank of Cleveland. "Theory Ahead of Rhetoric: Measurement and the 'New Economy'." 2000 Annual Report, 2000;

www.clevelandfed.org/Annualoo/essay.htm.

Federal Reserve Bank of Cleveland. "Rhetoric Aligned with Theory: Talking Productively about Interest Rates." 2001 Annual Report, 2001; www.clevelandfed.org/Annual01/essay.htm.

Federal Reserve Bank of Cleveland. "Deflation." 2002 Annual Report, 2002; www.clevelandfed.org/Annual02/essay.cfm.

Financial Times, November 6, 1975.

Franklin, Benjamin. A Modest Enquiry into the Nature and Necessity of a Paper-Currency. Philadelphia, PA: New Printing Office, 1729.

Friedman, Milton. A Theory of the Consumption Function. Princeton, NJ: Princeton University Press, 1957.

Friedman, Milton, and Schwartz, Anna J. "Has Government Any Role in Money?” Journal of Monetary Economics, January 1986, 17, pp. 37-62.

Hayek, F.A. Denationalisation of Money: An Analysis of the Theory and Practice of Concurrent Currencies. London: Institute of Economic Affairs, 1976, p. 29.

Jefferson, Thomas. Letter to Nathaniel Macon, Monticello, January 12, 1819.
Jordan, Jerry L. “Governments and Money.” Cato Journal, Fall/Winter 1996, 15(2-3), pp. 167-77; www.cato.org/pubs/journal/cj15n2-3-2.html.

Lincoln, Abraham. "Many Free Countries Have Lost Their Liberty.” Speech on the Subtreasury, Springfield, Illinois, December 26, 1839.

Madison, James. "The Utility of the Union as a Safeguard against Domestic Faction and Insurrection (continued)." The Federalist, No. 10. Franklin Center, PA: The Franklin Library, 1977 [1787].

Madison, James. "Alleged Danger from the Powers of the Union to the State Governments Considered." The Federalist, No. 45. Franklin Center, PA: The Franklin Library, 1977 [1788].

Madison, James. Letter to C.D. Williams, February 1820.

Madison, James. Letter to Mr. Teachle, March 15, 1831.

Mill, John S. Principles of Political Economy, Laurence Laughlin, ed. New York: D. Appleton, 1907.

Mises, Ludwig von. Human Action: A Treatise on Economics. New Haven, CT: Yale University Press, 1949.

Mundell, Robert. Uses and Abuses of Gresham's Law in the History of Money, 1998;

www.columbia.edu/ ram15/ grash.html.

Schwartz, Anna J. "Currency Boards: Their Past, Present, and Possible Future Role.” CarnegieRochester Conference Series on Public Policy, December 1993, 39, pp. 147-85.

Selgin, George. "Monetary Equilibrium in the 'Productivity Norm' of Price Level Policy.” Cato Journal, 1990, 10, pp. 265-87.

Selgin, George. Less than Zero: The Case for a Falling Price Level in a Growing Economy. IEA Occasional Paper. London: Institute of Economic Affairs, 1997.

Smith, Adam. An Inquiry into the Nature and Causes of the Wealth of Nations, Edwin Cannan, ed. Chicago: University of Chicago Press, 1976 [1776]. 


\section{APPENDIX}

\section{The American "Dollar" and Other Monetary Terms}

Just what is a "dollar" anyway? Everyone knows what gold is; they know what silver is; or at least there are some guys in the lab who will tell us the gold or silver content of any piece of metal. But a "dollar"? We have pieces of paper saying "one dollar" and other pieces of paper saying more dollars. We have stocks and bonds that are quoted as being traded for so many dollars and everyone keeps getting bills from the electric company, the gas company, and the IRS to send them so many dollars. Fortunately, employers have agreed to give us some dollars every month. Now, if we can just keep a balance between the number of dollars our employer promises to give us each month (assuming we can trust him) and the number of dollars all kinds of people say we must turn over to them-or we'll hear from their lawyers-we'll be okay.

Back to the beginning. What is this thing called a "dollar" that some people promise to give us and other people insist that we give to them? Well, it turns out that some valley in the Bohemian part of what we now call the Czech Republic has a lot to do with it. There, coins were made out of metal to help people make indirect exchanges between what they produced and what they wanted. The German word for valley is thal and it was common to refer to the metal coins produced in the valley as taler coins (the " $\mathrm{h}$ " being silent in German). That was often shortened to simply talers. In English, taler coins or talers sounded like dollar coins, or simply dollars, which was how the British referred to some metal coins made in Spain.

After the Spanish staked their claims on large chunks of the "new world," they started getting boat loads of gold and silver and stamping out a lot of coins. The Spanish monetary unit at the time was the real, and an eight-reales coin—a "piece of eight"—was referred to by English-speakers as a "dollar."

The American colonists kept their accounts in British pounds, shillings, and pence but they did not have available to them very many British coins. What they had mostly were Spanish and Portuguese coins, and the most common coin available to them was the Spanish "dollar" coin. Other coins available were the Spanish doubloon and pistole, the Portuguese moidore and johannes, and the French guinea and pistole. (Compared with these alternatives, we are fortunate that the coins the colonists had most of were Spanish dollars.)

Because the proportion of precious metal in all these coins varied and the colonists kept their books in terms of British pounds, it was necessary to define each of the various other metal coins in terms of British pounds. Keeping pounds as the unit of account but using Spanish dollars as the dominant medium of exchange was, of course, a very cumbersome arrangement. As British subjects, however, the colonists did not have a good alternative.

After the Declaration of Independence, it finally became opportune to think about a unique monetary system appropriate to the newly evolving nation. It seems that Thomas Jefferson quite pragmatically concluded that, since the most familiar coin in use was the Spanish dollar coin, it would be best to adopt a "dollar" as a standard. That meant a dollar had to be defined in terms of something of known value-other than British pounds. He also concluded that since "every schoolboy" could multiply and divide by ten, it would be best to have money units that were in terms of tenths of a dollar and multiples of ten dollars. Jefferson found the British use of eighths of a money unit to be cumbersome, at best. So, even though the Spanish had minted a "dollar coin" to be a "piece of eight" (consisting of eight reales), the colonists ultimately defined a dollar coin to be 24.75 grains of pure gold or 371.25 grains of pure silver. They further decided to mint a ten-dollar gold coin as well as a one-dollar gold piece and a onedollar silver piece, and to mint silver coins of one-tenth of a dollar and copper coins of one-hundredth of a dollar. 
Thus, the dollar-like every other thing that has served as money-was initially defined in terms of something of known value. Only gradually during the twentieth century did people come to accept that the word "dollar" stood in its own right as a concept of value. In other words, for almost 200 years a dollar was a claim to money—gold—and formally became money only in 1973 when the link to gold was severed.

\section{A Dollar as Money Is Distinct from Assets Denominated in Dollars}

Currently, there is only one source of dollars: the liabilities of Federal Reserve Banks. Everything else is a substitute for, or claim to, dollars. Actual dollars come in two forms: Federal Reserve notes and balances (deposits) at Reserve Banks that are maintained by depository institutions, such as a commercial bank. All transactions using Federal Reserve notes are final, certain, immediate, and (often) anonymous. That is why people like using them. Although you do not see it directly, all taxes paid by households and businesses to the federal government must be in the form of a transfer of ownership of balances held at a Federal Reserve Bank to the account of the U.S. Treasury at the Federal Reserve Banks.

People commonly exchange promises to pay and receive certain amounts of dollars at definite times in the future (bonds). Ultimately, the payor is giving a promise (which the courts will enforce) to acquire and deliver to the payee a certain number of Federal Reserve Bank notes or bank balances denominated in dollars (that are claims to balances at the Federal Reserve Banks) at a certain date in the future. Consequently, only dollars serve the function of money-indirect exchange-in the United States.

Claims to money—such as balances at financial intermediaries (banks and so on)—are a part of the monetary system. Yet, it is important to distinguish between various stores of wealth (mainly, financial assets) that are denominated in units of money and the entity that serves as money. The purchasing value of the dollar, for example, is not influenced by the aggregate "dollar value" of equity markets, debt markets, money-market funds, foreign-held "eurodollar" balances, or any other instruments that are specified in legal contracts to pay and receive dollars.

\section{Some Monetary Terms}

Coin metal tokens used as media of exchange, either full-bodied (i.e., containing the amount of precious metal indicated by the standard) or merely representational (like paper notes)

Currency (i) name of a unit of account, e.g., "dollar," “pound," “yen”; (ii) paper notes used as a medium of exchange

Monetary standard the (legal) (official) definition of the value of a currency in terms of something else, like, e.g., gold, silver, or the discretion of the government (fiat)

Dollar (i) liability of Federal Reserve Banks; (ii) U.S. unit of account and medium of final exchange; (iii) U.S. legal tender-a judicially enforceable right to receive payment or compensation in a certain currency

Indirect exchange interpersonal exchange of goods or services that employs an intermediate entity (money) rather than direct barter of final consumables

Money (i) standard of value; (ii) media of exchange used in indirect exchange; (iii) that entity that economizes best on the use of other real resources in gathering information about relative values and conducting transactions 